\title{
Dynamics of intermodal logistical systems on containerisation and road transportation in Durban, South Africa
}

\begin{abstract}
Authors:
Nerissa Govender

Thokozani P. Mbhele ${ }^{2}$

Affiliations:

${ }^{1}$ Aramex South Africa,

Durban, South Africa

${ }^{2}$ School of Management, IT and Governance, University of KwaZulu-Natal, Westville Campus, South Africa
\end{abstract}

\section{Correspondence to:}

Thokozani Mbhele

Email:

mbhelet@ukzn.ac.za

\section{Postal address:}

Private Bag X54001, Durban

4000 , South Africa

\section{Dates:}

Received: 14 July 2014

Accepted: 06 Sept. 2014

Published: 05 Dec. 2014

How to cite this article: Govender, N. \& Mbhele, T.P. 2014, 'Dynamics of intermodal logistical systems on containerisation and road transportation in Durban,

South Africa', Journal of Transport and Supply Chain Management 8(1), Art. \#150, 10 pages. http://dx.doi. org/10.4102/jtscm.v8i1.150

\section{Copyright:}

(C) 2014. The Authors. Licensee: AOSIS

OpenJournals. This work is licensed under the Creative Commons Attribution License.

\section{Read online:}

The underlying port operations in Durban, South Africa, epitomise intense global competitiveness in the intermodal logistics chain. The link between containerisation and the road transport network can falter as a result of the dynamics of the logistics system. The main objective of the study was to establish the extent of the intermodal challenges of logistical systems on containerisation to which the role of intermodal sea-road freight transportation enhances the logistical competitiveness. It further examined the intermodal relationship on containerised freight between the challenges of containerisation processes and the effects on road freight transport mode. The impact of containerisation on intermodalism, the sea-road freight transport network and the technological attributes of security-based systems and logistical tracking protocols influence the systematic movement of containers on Durban's public roads.

\section{Introduction}

\section{Background}

The challenges of containerisation from the logistical linkage between the container shipping network and the road freight transportation network are impacting on the Port of Durban, KwaZulu-Natal (KZN) Province, South Africa. Road transportation and containerisation have retained an economically beneficial relationship in Durban regarding the value-creation of Port activities. This linkage gives rise to various challenges such as overweight containers, infrastructural damage and sometimes unbearable traffic congestion. Containerisation is therefore defined as 'the system by which containerised freight is transported intermodally' (Pienaar \& Vogt 2009:276). Containerisation and the development of an intermodal transport system have a profound effect on the shipping industry, its structure, management and operations. Intermodality is described as the movement of cargo from shipper to consignee by at least two different modes of transport under a single rate, through-billing and through-liability (Hayuth 1987; Mokhtar 2013). The road freight transportation network in this study describes the effective planning and organisation of the operations and infrastructure in the surface transport activities (national roads and highways) as a set of interrelated and interconnected nodes on the underlying economic business practices of intermodal freight transportation in a network.

Similarly, this study adopts the meaning of intermodal transport as the use of at least two different modes of transport in an integrated logistical system network, in a door-to-door transport chain (Organisation for Economic Development and Cooperation 2001). An intermodal logistics chain is defined in this study as the integration and complementarity between different transport modes (in this case road freight transport and sea shipping transport modes) that provide economies of scope and distance for a more efficient movement and geographical positioning of containerised cargo using two integrated value-adding systems of transport modes. In the same light, Bowersox et al. (2013:4) describe that the integrated value-creating logistics serves to link and synchronise the overall supply chain as a continuous process and is essential for effective supply chain connectivity. According to Hanaoka and Regmi (2011:16), the development of intermodalism requires the consideration of three of its attributes, such as transport links, transport network nodes and the provision of efficient services, to achieve an efficient intermodal sea-road freight transport system. This study seeks to create awareness amongst road freight transport operators on strategic optimisation factors and various challenges, and to consciously position the Durban Port as a larger gateway for inbound and outbound intermodal transportation networks.

\section{Research problem and objectives}

The intermodal logistical system has influence on the delivery of containers that manifests congestion in the areas surrounding the Port of Durban. Road transportation is the dominant 
mode in Durban, with more than $87 \%$ of imported and exported freight being carried by this mode of transport. There has been a significant increase in traffic at the Port of Durban, with adverse effects on infrastructure (Kunene \& Allopi 2011) despite the fact that the terminals have been enlarged to accommodate larger freight. The road transport networks are essential for the movement of containerised freight within certain vicinities and absorption of the port operations processes. The size and weight of the trucks and overweight containers cause road damage, especially in the Bayhead, Quayside, Maydon Wharf, Francois (Rick Turner), Wisely, South Coast, Bluff and Iran Roads. The cycle time and delivery lead time delays are caused by the need to prevent overweight capacity, traffic congestion, accidents and the implementation of weighbridge protocols. The innovative technological systems and road infrastructural containership for port users and service providers become increasingly interrelated and integrated to consolidate the system of intermodal transportation. The integrated systems of containerisation on sea-road freight transport network and supply chain optimisation strategies reflect South Africa's eminently prosperous, increasing share of international trade.

The main purpose of this study is to explore the impact of the intermodal systems on operations and infrastructure, supply chain technological advancements and traffic congestion at the inbound and outbound Durban Port networks. Its first objective is to establish the extent of the intermodal challenges of logistical systems on containerisation to which the role of intermodal sea-road freight transportation enhances the logistical competitiveness. Secondly, it assesses the effects of strategic optimisation factors in the intermodal linkage between the road freight transport mode and the absorption of inbound and outbound traffic congestion in the Port of Durban. Thirdly, it examines the intermodal relationship on containerised freight between the challenges of containerisation processes and the effects on road freight transport mode. Finally, it establishes the effects of the supply chain technological systems utilised for security-based activities, competitive information sharing and the logistical tracking and tracing of containers in-transit on public roads as well as vessels across the country.

\section{Literature review}

\section{Background to containerisation}

Cargo containers have emerged as a fundamental means of transporting manufactured goods in a supply chain logistical system. The need for containers arose when the movement of individual boxes, barrels and crates became time-consuming and labour intensive at ports (Northport 2009). The bulk transportation of goods resulted in the introduction of containers in the 1950s, followed shortly thereafter by the building of containerships (ExportHelp 2010). This promoted intermodalism in which a container is moved via various modes of transportation in a simpler, logistical process, hence expanding trade amongst countries
(Northport 2009). This logistical process has improved tremendously since the early era, when cargo ships spent more time loading and dispatching shipments at ports than on actual transportation via sea (Cudahy 2006). The Durban Container Terminal has the largest capacity to handle containers in the southern Hemisphere (KZN Department of Transport 2011). It was established in 1977 and moved approximately 78493 containers in its first year of operations (Transnet 2011a). Currently, the terminal has six berths and handles 1474978 containers a year, including various types of containers, from International Organisations for Standards (ISO) containers of general purpose to abnormal containers (Transnet 2011a). These container standards were institutionalised in the 1960s with the growth of intermodalism in mind in order to achieve commonality amongst freight and facilitate movement across different modes (Coyle et al. 2011). Containerisation contributes to a higher efficiency in the development of intermodal and multimodal transport operations.

\section{Theoretical framework of the study}

The movement of freight in containers increases the efficient handling and storage of products using containers ranging from ISO to technologically improved smart containers. The network theory views any system as a set of interrelated actors or nodes (Tate, Ellram \& Golgeci 2013:266), whereby the actors can represent entities at various levels of collectivity and linkage, such as persons, firms, countries and other participants in the network (Borgatti \& Li 2009:2). Intermodal networks represent an important way to diffuse ideas and practices amongst road freight transport operators, freight forwarders, intermodal supply chain customers and the Port of Durban within the network. Network theory enhances the understanding of the role of supply chain logistics partners, governmental organisations and Port of Durban on both inbound and outbound intermodal transport networks. Although the driving forces behind intermodal economic practices include government regulation, customer requests and costs savings (Rugman \& Verbeke 1998:363-375), collaboration in a supply chain network is required for extended enterprises to share knowledge and skills on consolidated diffusion of intermodal economic practices and Port of Durban operational process initiatives (Pagell, Wu \& Murthy 2007:133-143).

Diffusion of innovation is influenced by leadership attitude toward change, interconnectedness and system openness within the context of technology (Rogers 2003) and top management support within the organisation context (Oliveira, Thomas \& Espadanal 2014:497). The technologyorganisation-environment framework (Tornatzky \& Fleischer 1990) assists in providing a more comprehensive perspective for understanding Transnet's central IT adoption (Navis SPARCS N4) (Transnet 2011b) by including the technology, organisation and environment contexts for the inbound and outbound Port of Durban intermodal transport network (Zhu et al. 2006:601-616). If the diffusion is the process in which an innovation is communicated over time through certain 
channels amongst members of a social system (Rogers 2003), the principal characteristics of the Transnet's central supply chain IT system are applied to the planning of road freight transport infrastructure and positive impacts for intermodal transport management, particularly planned Port operations processes and controlled traffic congestion in surrounding Port of Durban.

Arguably, the adoption theory, points out that many innovations do not achieve the expected results for failure to satisfy the requirements of potential adopters (Figueiredo 2005) relating to an efficient intermodal freight logistics chain. The dynamic capability theory elaborates more on the principles of how the Port of Durban and intermodal freight logistics partners can integrate, build or deploy and reconfigure their internal resources and external competencies in changing the containerisation environment (Newbert 2007; Teece, Pisano \& Shuen 1997). The dynamic capabilities are critical for performance in the intermodal environments as they determine the flexibility, compatibility, clockspeed and delivery efficiency (Teece 2007). According to the institutional theory, external isomorphic pressures from competitors (Ports of Richards Bay, Port Elizabeth and Cape Town), trading partners (intermodal and multimodal transport services providers, freight forwarders and bonded warehouse) and customers (all Transnet Port Terminal customers) likely induce forms to engage in certain supply chain logistics management practices (Sodero, Ravinovich \& Sinha 2013). This unique link in the logistics process networks provides direct availability to clients and allows for long haulage.

\section{Interface of containerisation and road transportation network}

Road transport is described as the most effective and flexible mode of transportation in South Africa; it has overtaken rail transportation and dominates the freight movement because of the convenience and services it offers. The road transport network offers faster delivery, cheaper packing systems and shorter lead times. As a result of containerisation and the road transportation network, South Africa faces the challenge of the carriage of containers that exceed the gross mass weight laid down by legislation (Department of Transport 2011). This leads to increased liability costs and infrastructural damage to major roads and national highways, as well as being the primary cause of many road accidents. Poor road conditions can result in higher costs and litigation, impacting containerisation, the intermodal activities and the road transportation network (Miller 2001; Teravaninthorn \& Raballand 2009).

The increased volume of road freight networks has aggravated traffic congestion surrounding the Port and storage depot areas. The traffic congestion is the result of the uneven split between road and rail transportation (Council for Scientific and Industrial Research 2010). Whilst $88.7 \%$ of containerised freight is transported via road, only $11.3 \%$ travels via rail (Council for Scientific and Industrial
Research 2010). To address road congestion, the KwaZuluNatal Department of Transport implemented a system whereby trucks enter the Port terminals based on scheduled appointments with the freight forwarder (KZN Department of Transport 2011). Freight forwarders act as fourth-party service providers in transporting containers from shipment through the road transport network and they are fully liable for the freight in their possession from its origins in ports to the destination of final customers (Cassidy 2010). Contracts between suppliers of containerised freight and the final user need to be prioritised in order to avoid liability claims and legal issues (Goga 2012).

\section{Technology for containers}

Efficient container management is required to maintain safe and smooth operations; radio-frequency identification is able to trace a container's location at a terminal, ensure the maintenance of vehicles delivering containers through the road network, calculate the loading of the container and ascertain any problems encountered with containers at terminals (Barro-Torres et al. 2010). It enhances the security of containers (container identification, determination of seal breakages on container) (ISO 2009) and improves efficiency at ports (Barro-Torres et al. 2010). Dedicated short-range communication allows for vehicle traffic to be monitored at portside (Coronado Mondragon et al. 2012). This wireless network facilitates the movement and coordination of road transport networks in and around ports through communication using improved logistical applications. Scanners and X-ray technology are used during inspection and customs clearance at ports and terminals to determine hazardous substances, whilst an electronic seal is attached to the door of the container (Roberti 2005) and is used to detect when containers' doors have been opened by unauthorised personnel. Security aspects of the supply chain consist of a series of layers that promote the safe delivery of containers which have not been subject to theft and mishandling (Raymond 2006).

\section{South African perspective on technology}

Although wireless technology promotes the advancement of tags that assist with the tracking and tracing of containers (ISO 2009), Transnet's central system provides Transnet Port Terminals (TPT) customers with a seamless and integrated service across the ports. The TPT became the port operator to the Navis SPARCS N4 terminal operating system from a central location across 21 marine and rail terminals. Transnet's central system affords TPT customers with decreasing costs of doing business and increasing competitiveness within South Africa through a more effectively integrated supply chain (Ngcobo 2009:1). If the web-based SPARCS N4 operating system governs the movement of all container logistics and operations, theimproved intermodal logistical system support should lower the supply chain operating costs through greater control over resources and intelligently respond to changes or disruptions in the flow of cargo. Havenga, Simpson and De Bod (2012:38) highlight that national freight logistics costs are high, with road infrastructure challenged by increasing 
concern of environmental impact, and the authors believe that intermodal solutions could reduce transport costs. Scheinberg (2009:2) adds that Navis allows 'inter-terminal integration and synchronised planning linked in the chain to track scheduled vessel progress and plan efficiently across several terminals in the country'. Musa, Gunasekaran and Yusuf (2014:176) assist in describing tracking as the determination of the identity and state of a product, whilst tracing is described as inference to the product's path and history from downstream to upstream of the supply chain.

This end-to-end supply chain visibility by tracking and tracing reflects a means of security and process control and optimisation in multisite management systems. The central system deems to offer a certain level of flexibility and depth of effective functionality to abate the challenges of containerisation on intermodalism in a sea-road freight network. The centralised visibility of real-time information between TPT operations and cluster of logistics customers improves supply chain intermodal logistical systems and allows streamlining operations to realise the benefits of multisite management (Port Technology 2014). In a competitive environment, the profitability of a focal company such as Transnet depends strongly on its ability to manage complex relationships with its business partners, especially the freight forwarders (Caridi et al. 2010:593). The focal company is identified by stakeholders, including customers, as being responsible for the specific modes, products or services and the coordination and integration of physical and technological resources and centrally synchronised real-time information flows (Caridi et al. 2014:1).

\section{Research method and design Design}

This study employed an exploratory research design to examine the processes and events that unfold when containers are in-transit via the road transport network. According to Sekaran and Bougie (2010:103), exploratory research is undertaken when not much research has been conducted on a subject. Quantitative research methods were employed to gather statistical information on the opinions of the target population using a questionnaire instrument (Cooper \& Schindler 2010:102). A cross-sectional study gathers data once over a time horizon of weeks or months (McBurney \& White 2007:341) and conclusions regarding the larger population can be drawn instantaneously as a result of the shorter time period (Shuttleworth 2010). A cross-sectional study was deemed appropriate to gather data regarding challenges of containerisation, dynamics of intermodality and the road freight network.

Sampling design is the method of choosing the individuals and groups that best represents a population as part of a study' (Beins \& McCarthy 2012:93); this requires that decisions be made regarding the population and sample requirements before gathering the relevant data. Cooper and Schindler (2010:374) underpin that one can eventually make conclusions and recommendations about the population based on the selection of limited elements. This study employed convenience sampling as well as judgement sampling. In probability sampling, every element in the sample has a definite chance of being chosen (McBurney \& White 2004:248) and processes need to be established to ensure that this is the case (Sekaran \& Bougie 2010; Trochim 2006). In this study, the researcher chose to use judgement sampling, a non-probability technique, where those individuals whom the researcher has considered to possess experience and knowledge in a specific industry were selected (Cooper \& Schindler 2010:397). In nonprobability sampling, a specific element is chosen and these elements have no idea or probability of being sampled (Beins \& McCarthy 2012:99). The sample was made up of individuals from depots, freight forwarders, road freight networks operators, fourth-party logistics service providers and the intermodal related activities.

\section{Procedure}

A total of 110 valid responses were collected; the descriptive statistics on strategic optimisation factors are shown in Table 1 . The valid sample replies (110 out 180 questionnaires constituting a $61 \%$ return rate) comprised 39 respondents from container depots, 35 road transport network operators, 19 fourth-party logistics service providers, 7 freight forwarders and 10 respondents from the intermodal related activities. Walker (2010:27) notes that in order to achieve specific research objectives, the sample size should be large enough in order to generate statistical findings. The target population in this study ranges from container depots in the area of Durban, under eThekwini Municipality, KwaZulu-Natal Province, South Africa. The data collection instrument was a questionnaire as the primary source and it was administered by the researcher to targeted individuals (Walliman 2001:197). As this was an exploratory study, new information was sourced using

TABLE 1: Descriptive statistics on strategic optimisation factors.

\begin{tabular}{|c|c|c|c|c|c|c|c|c|c|}
\hline Statistic & $N$ & Range & Min & Max & Mean & $\begin{array}{l}\text { Standard } \\
\text { deviation }\end{array}$ & Variance & Skew & Kurt \\
\hline Full-truck load lane & 110 & 4.00 & 1.00 & 5.00 & 4.254 & 0.871 & 0.760 & -1.284 & 2.048 \\
\hline Delivery schedules & 110 & 4.00 & 1.00 & 5.00 & 4.236 & 0.985 & 0.971 & -1.489 & 2.264 \\
\hline Routing traffic overflow & 110 & 4.00 & 1.00 & 5.00 & 4.136 & 1.060 & 1.128 & -1.354 & 1.501 \\
\hline Peak time restrictions & 110 & 4.00 & 1.00 & 5.00 & 3.981 & 1.010 & 1.027 & -0.879 & 0.413 \\
\hline Reduction of trucks & 110 & 4.00 & 1.00 & 5.00 & 3.772 & 1.110 & 1.241 & -0.874 & 0.193 \\
\hline Night transport network & 110 & 4.00 & 1.00 & 5.00 & 3.500 & 1.410 & 1.995 & -0.587 & -0.860 \\
\hline Valid $N$ (listwise) & 110 & - & - & - & - & - & - & - & - \\
\hline
\end{tabular}


self-administered questionnaires. These questionnaires posed specific questions with closed alternative answers (McBurney \& White 2004:244). The questionnaire was structured into four sections, including section A: biographical data and organisational profile, section $\mathrm{B}$ : dichotomous questions (Yes or No), section C: ranking from 1 to 4 in terms of most important (4) to least important (1) on underlying overweight containers and section $D$ : the degree of agreement or disagreement (where 5 represented 'strongly agree' and 1 represented 'strongly disagree' on the 5-point Likert scale). The relevant letters (gatekeeper's letter, ethical clearance certificate and consent letter to ensure confidentiality and anonymity) were constantly depicted to the gatekeepers where the researcher was given permission to engage, distribute and collect the questionnaires. The questionnaires were coded scientifically by constructs and data codes with the use of IBM's (2010) SPSS Statistics version 19. SPSS generated statistics to be used for data analysis and interpretation.

\section{Assessment of reliability and validity}

Researchers need to ensure the measure of the right concept and measure the stability and consistency of the concept, which is determined by reliability. This study tested reliability using Cronbach's alpha, which is a test for internal consistency. Cronbach's alpha values (0.60) show construct validity and that the constructs are measured with sufficient reliability. This statistic provides an indication of the average correlation amongst all the items: reliability is achieved as Cronbach's alpha value is equal and/or greater than 0.60 (Bryman \& Bell 2007:164). Validity can be determined by applying certain validity tests in order to measure the right concept (Bryman \& Bell 2007:165). Content validity measures the adequacy of the sample (McBurney \& White 2004:129), whilst criterion validity examines the relationship between scale scores and some specified scores and construct validity measures the degree to which the scale measures the underlying concept it claims to measure (Beins \& McCarthy 2012:68).

\section{Results \\ Descriptive statistics}

Descriptive statistics are used for measures of central tendency and dispersion where the items measured belong to the interval scale section of a questionnaire (Sekaran \& Bougie 2010:322). These statistical results reveal that the dynamics of the logistical system in the region are attributed to the strong linkage between containerisation and the road freight transport network. The interval-scaled descriptive statistics relate to the strategic optimisation factors on the linkage between the road freight network and containerisation system to alleviate traffic congestion within the region. Fu et al. (2014:21) describe supply chain optimisation as a set of approaches utilised to efficiently integrate supply chain partners for a leanbased transformation process and efficient distribution in the right quantities, locations and time in order to minimise system-wide costs, whilst satisfying service level requirements. Both the appropriate inbound and outbound port strategy and electronic information sharing are dispensable in reducing the dynamics of intermodal freight logistical challenges and improving port operations processes performance ( $\mathrm{Li} 2013: 1907)$.

The study revealed that the most significant priority for an optimised road freight network is that of containerised full-truck loads $(\mathrm{M}=4.2545$, s.d. $=0.87195)$ and allocation of a separate lane in order to mitigate traffic congestion (Table 1). The statistics further indicated that two other significant factors are closer synchronisation of delivery time schedules using dedicated short-range communication and global positioning systems and strategic routing to stabilise traffic flow. The statistics depicted that if the delivery time schedules $(\mathrm{M}=4.2364$, s.d. $=0.98547)$ are collaboratively synchronised by efficient freight forwarders, road freight transport $(\mathrm{M}=4.1364$, s.d. $=1.06200)$ could be directed to the least traffic overflow area. In terms of alleviating traffic congestion through regulation, the findings tentatively suggested restricted operations during peak times $(\mathrm{M}=$ 3.9818 , s.d. $=1.01300)$, reducing the number of trucks on the roads $(\mathrm{M}=3.7727$, s.d. $=1.11400)$ and instituting a night transport network $(\mathrm{M}=3.5000$, s.d. $=1.41200)$ for road freight containership.

\section{Hypotheses testing}

The research study focused on strategic optimisation factors in the intermodal linkage between the road freight transport network and containership in order to absorb and ameliorate road traffic congestion. This study sought hypothetically to link the optimisation factors with critical decision-making on the part of various respondents in various fields of employment in the sector, transport modes and advances in supply chain technology. The hypotheses are tested using three diverse sets of bivariate-cross-tabulation, analysis of variance (ANOVA) and multiple regression analysis, as follows below.

\section{Hypothesis set one}

The first hypothesis set was as follows:

- Hypothesis $\mathbf{1}_{\mathrm{A}}$ : Decision-making in the various fields of employment in this sector has made a positive contribution to efficiently synchronised-quasi-real-time delivery schedules.

- Hypothesis $\mathbf{1}_{\mathrm{B}}$ : Decision-making in the various fields of employment in this sector positively underpins operational restrictions and requirements to avoid road highways during peak times.

- Hypothesis $\mathbf{1}_{\mathrm{C}}$ : Decision-makers in the various fields of employment in this sector agree to use road transportation networks primarily at night.

The contingency table generated a relationship between bivariate-based variables to determine the appropriate associations from 110 valid cases at significance level (0.05). 
TABLE 2a: Strategic optimisation factors.

\begin{tabular}{|c|c|c|c|c|c|c|c|c|}
\hline $\begin{array}{l}\text { Strategic optimisation } \\
\text { factors }\end{array}$ & $\begin{array}{c}\text { Strongly } \\
\text { disagree (\%) }\end{array}$ & $\begin{array}{c}\text { Disagree } \\
(\%)\end{array}$ & $\begin{array}{c}\text { Neutral } \\
(\%)\end{array}$ & $\begin{array}{c}\text { Agree } \\
(\%)\end{array}$ & $\begin{array}{l}\text { Strongly } \\
\text { agree (\%) }\end{array}$ & $\begin{array}{c}\text { Total } \\
\text { agreement (\%) }\end{array}$ & $(D f=1 ; 16)$ & Sig. \\
\hline Delivery time & 3.6 & 0.9 & 14.6 & 30.0 & 50.9 & 80.90 & 50.743 & 0.000 \\
\hline Peak time & 2.5 & 4.5 & 21.8 & 33.6 & 37.6 & 71.20 & 36.472 & 0.002 \\
\hline Night transport & 16.5 & 4.5 & 24.5 & 21.8 & 32.7 & 54.50 & 32.757 & 0.008 \\
\hline
\end{tabular}

$D f$, degrees of freedom; sig., significance level.

TABLE 2b: Fields of employment.

\begin{tabular}{lccccc}
\hline Fields of employment & Intermodal (\%) & Fourth-party (\%) & Road freight (\%) & Freight forwarder (\%) & Depot (\%) \\
\hline Percentage agreement & 9.0 & 17.3 & 31.8 & 3.4 \\
\hline
\end{tabular}

Table 2 depicts the relationship between the strategic optimisation factors (delivery time, peak time and night transport - Table 2a) and fields of employment (intermodal, fourth-party, road freight, freight forwarder and depot Table $2 b$ ) on the underlying magnitude of agreement amongst the statements. The overwhelming majority $(80.9 \%)$ of the respondents concurred that the quasi-realtime delivery schedules should be properly and efficiently synchronised across enterprises with freight forwarders. Furthermore, $71.2 \%$ agreed that stringent rules should be applied to road freight transport operations during peak times in order to alleviate traffic congestion on the road networks. In terms of the percentage agreement amongst the fields of employment, depot (35.5\%) and road freight (31.8\%) players represent a combined majority of the respondents (67.3\%) that tentatively supported closer synchronisation amongst delivery partners, night operations and restricted operations during peak times. Optimal delivery times, restricted operations during peak times and night transport operations were moderately supported by intermodal $(9.0 \%)$, fourth-party $(17.3 \%)$ and freight forwarders $(6.4 \%)$. The tests generated significance levels less than 0.05 (degree of freedom $=1 ; 16$ ), which failed to accept the null hypotheses. This study therefore infers that the proper alignment of quasi-real-time delivery schedules requires a closer synchronisation with freight forwarders in order to enhance logistical supply chain performance in road freight networks. In order to alleviate road freight congestion, the study points to night transport operations and operational restrictions during peak times.

\section{Hypothesis set two}

The second hypothesis set was as follows:

- Hypothesis $2_{\mathrm{A}}$ : The road freight transport mode has an essential relationship with either delivery time schedules, or transport routing, peak times, full-truck load lane, a reduction in the number of trucks or night transportation.

Cohen et al. (2003) describe multiple regression as a flexible method of data analysis that may be appropriate whenever a quantitative criterion variable is to be examined in relation to any other factors expressed as predictor variables. The Pearson correlation matrix indicated an acceptable correlation between all possible pairs of variables and a significant positive correlation $(p<0.05)$ with a dependent measure (transportation mode). The criterion variable was positively correlated to delivery schedules, routing
TABLE 3: Multiple regression analysis with transportation mode (dependent variable).

\begin{tabular}{lll}
\hline $\begin{array}{l}\text { Regression results: Dependent } \\
\text { variable - Transportation mode }\end{array}$ & Model 1 & Model 2 \\
\hline Constant & $0.206(0.000)$ & $0.289(0.000)$ \\
Prolong delivery & $-0.206(0.031)^{* *}$ & $-0.259(0.008)^{* *}$ \\
\hline Full-truck load lane & - & $0.209(0.031)^{* *}$ \\
$R$ & 0.206 & 0.289 \\
$R^{2}$ & 0.042 & 0.083 \\
Adjusted $R^{2}$ & 0.033 & 0.066 \\
$F$ & $4.772(0.031)$ & $4.789(0.010)$ \\
$D f$ & 1.108 & 1.107 \\
Collinearity Statistics: Model 1 & $T=1.000$ & VIF $=1.000$ \\
Collinearity Statistics: Model 2 & $T=0.936$ & VIF $=1.069$ \\
Durbin-Watson & 2.036 & 2.036 \\
\hline
\end{tabular}

$R^{2}$ coefficient of determination; $D f$, degrees of freedom; $F, F$-value; $T, T$-value; VIF, variance inflation factor.

${ }^{* *} p<0.05$

traffic, peak time, full-truck load, reduction in trucks, night transport networks inspections and risk reduction, advanced technologies, security protocols, prolong delivery times and proper documentation when using the 5-point Likert scale. Only two predictor variables (prolong delivery and fulltruck load lane) were entered into prediction model 2 after stepwise procedure with a multiple $R$ of 0.289 and both prolong delivery and full-truck load lane were significantly entered into the regression equation.

The multiple regression technique was chosen to hypothetically determine the relationship between the dependent variable (transport mode - road freight transport network) and predictor variables. Table 3 explains only $8.3 \%$ of the variance (improved from $4.2 \%$ in model 1 ) in the road freight transport mode. The second model produced two dimensions; prolonging delivery $(\beta=-0.25, p=0.008)$ and a full-truck load lane $(\beta=0.209, p=0.031)$ at significance level of 0.05 were found to be considerably related with the road freight transport mode. In terms of an efficient road freight transport mode to alleviate road congestion, this is predictably related to full-truck loads being allocated a separate lane and further associated with prolonging delivery times to customers.

These results link the road freight transport mode and the challenges of containerisation as determined by regulated road freight infrastructural design for full-truck loads and the efficient customs clearance procedures to enhance the on-time delivery service level to customers. Two models from the stepwise procedure were produced by regression 
analysis without concern for the multicollinearity problem, with both the variance inflation factor below 10 and tolerance more than 0.10 , reflecting acceptable positions. In the case of normality, the scatter plot maintained points between the ranges of -3.3 and +3.3 without any outliers. The output stated the measure $(\min .=0.001, \max .=0.149)$ of leverage on how much an observation influences the regression coefficient and this study revealed acceptable hat values within the rule of thumb (leverage goes from 0 to 1 ). In examining the degree of autocorrelation, model 2 indicated the value (2.036) of the Durbin-Watson statistic to be consistent with the ideal range values (between 1.5 and 2.5), with no problems related to autocorrelation.

\section{Hypothesis set three}

The third and final hypothesis set was as follows:

- Hypothesis $3_{\mathrm{A}}$ : Supply chain technological advancements in container-based road freight transport networks produce mean differences towards either containership theft, or in-transit communication, systematic risk or inbound and outbound coordinated scheduling.

The ANOVA uses a single-factor, fixed-effects model to compare the effects of one treatment on a continuous dependent variable. Table 4 shows the ANOVA tests that were conducted between advanced technologies and both containership theft and in-transit communication. The Levene's test of homogeneity of variance was greater than the level of significance (0.05); hence, there was no reason for further robust tests of equality of means as the assumption had not been violated. The underlying variables between groups showed significance levels of all greater than 0.05 and the Turkey test depicted the means without difference to each other; thus, there was no significant difference observed through the means tests between advanced technologies and both containership theft and in-transit communication. The second component of the set investigated whether the improvement in technology mitigates the systematic risk in transportation whilst enhancing the scheduling of container movement on the basis of advances in technology. Both systematic risk and inbound and outbound scheduling indicated significant difference amongst the scores of means, with $F=3.649$, $p=0.15$ and $F=4.255, p=0.007$, respectively. Technological advancement can tentatively provide significant mean differences in mitigating systematic risk in the road freight transportation networks and closely synchronised inbound and outbound scheduling systems.

\section{Discussion}

The road transport network forms an important concept in the logistics system where the delivery of containers reflects congestion in the areas surrounding the Port of Durban. The first study objective attempts to establish the extent of the intermodal challenges of logistical systems on containerisation to which the role of intermodal sea-road freight transportation enhances the logistical competitiveness. In order to stabilise the traffic overflow in a competitive environment, strategic routing depends on collaboratively synchronised delivery time schedules by efficient freight forwarders as well as congruent inbound and outbound port scheduling systems. Although the minibus or taxi industry has been piloted with a separate road lane in the Durban region, priority has not yet been given to containerised full-truck load in allocating separate lane to alleviate traffic congestion. To a certain extent of the intermodal challenges of logistical systems on containerisation, it is established that efficient electronically enabled containership management systems improve the integrated movement of containerised freight, intermodal transport linkage and better coordination of road freight transport mode in and around the Durban Port through improved technological communication. The antecedents of Transnet's central IT system adoption intention based on the technology-organisation-environment framework incorporate perceived benefits, perceived costs, Port size, top management support, information sharing culture and business partner influence (Teo, Lin \& Lai 2009:972).

The second objective assesses the effects of strategic optimisation factors (delivery time, peak time and night transport) in the intermodal linkage between the road freight transport mode and the absorption of inbound and outbound traffic congestion in the Port of Durban. The utilisation of full-truck load night operations as well as the constrained use of highways by road freight during peak times is considered within economic and social regulatory imperatives for logistical supply chain performance. Optimal delivery times, restricted operations during peak times and night transport operations are moderately supported by intermodal road freight operators, fourth-party and freight forwarders. Whilst the monitored restriction of peak times is convenient, with less traffic affecting the road freight networks, the poorly managed restriction eventually creates less responsive logistics supply chain performance as well as less flexible delivery time schedules. Arguably, the peak time restrictions may not always be congruent with scheduled Port times of arrival and departure and extensive consultations are required with all logistics supply chain partners, especially

TABLE 4: Analysis of variance on supply chain technological advancements.

\begin{tabular}{|c|c|c|c|c|c|c|c|c|c|c|}
\hline \multirow[t]{2}{*}{ Set Three: ANOVA } & \multicolumn{5}{|c|}{ ANOVA } & \multicolumn{3}{|c|}{ Homogeneity } & \multicolumn{2}{|c|}{ Robust test - Sig. } \\
\hline & B & $\mathbf{w}$ & $F$ & $D f$ & Sig. & Levene-Stat & Sig. & $D f$ & Welch & Brown-Forsyth \\
\hline Containership theft & 3.439 & 100.416 & 1.210 & - & 0.310 & 0.946 & 0.421 & 3.106 & 0.160 & 0.426 \\
\hline $\begin{array}{l}\text { In-transit } \\
\text { communication }\end{array}$ & 0.713 & 102.335 & 0.234 & 3.101 & 0.872 & 2.263 & 0.086 & 3.101 & 0.845 & 0.904 \\
\hline Systematic risk & 9.490 & 87.557 & 3.649 & 3.101 & 0.015 & 1.103 & 0.352 & 3.101 & 0.021 & 0.035 \\
\hline $\begin{array}{l}\text { Inbound or outbound } \\
\text { coordinated scheduling }\end{array}$ & 11.154 & 90.005 & 4.255 & 3.103 & 0.007 & 2.309 & 0.081 & 3.103 & 0.019 & 0.031 \\
\hline
\end{tabular}

B, between groups; W, within groups; $D f$, Degrees of freedom; Sig., Significance level; $F, F$-value; ANOVA, analysis of variance. 
freight forwarders. Notably, the better positioning of the Durban Port on the underlying containerisation architecture of the intermodal freight transport network provides access to novel information and innovative ideas embedded in a supply chain network (Kim 2014), whilst reciprocally enhancing the performance of TPT customers.

The third objective examines the intermodal relationship on containerised freight between the challenges of containerisation processes and the effects on road freight transport mode. The multiple regression technique was chosen to determine hypothetically the intermodal relationship in this study. Efficient road freight transport networks are explicitly dependent on customs clearance procedures that determine on-time delivery service to customers. Arguably, delays and prolonged delivery times to customers cannot entirely be attributed to challenges within the road freight networks; future research should investigate port customs clearance procedures.

The final objective uses the ANOVA on hypothetical statements to establish the effects of the supply chain technological systems utilised for security-based activities, competitive information sharing and the logistical tracking and tracing of containers in-transit on public roads as well as vessels across the country. Technological advancements have the potential to significantly mitigate systematic risk in the road freight transportation networks and closely synchronise inbound and outbound scheduling systems. In light of the growing influx of containers, the time-consuming yet efficient customs clearance procedures at the Durban Port and advancements in technology to mitigate systematic risk should collaboratively improve intermodal scheduling systems to create options for road freight transportation networks. Technological features play an important role in preventing theft, mitigating risk, monitoring containers and tracing shipments. Technology protocols for security-based customs clearance and the tracking of shipments should be formalised by governmental regulations for the transport sector. This prevents illegal activities and limits criminal activities in-transit.

\section{Limitations of the study}

The study has considered road transport network operators, fourth-party logistics service providers, freight forwarders and respondents from the intermodal related activities only in the Durban region. Owing to the variety of mediumsized companies with operations relating to the Durban Port, the findings from the questionnaires focused on the opinions of individual participants. The results presented are representative of the selected respondents and therefore cannot be assumed as representative of the various South African ports and surrounding regions or the entire logistics, maritime or transport industries.

\section{Recommendations}

The main purpose of this study was to explore the impact of the intermodal systems on operations and infrastructure, supply chain technological advancements and traffic congestion at the inbound and outbound Durban Port networks. The hypothetically configured four objectives produced specific recommendations based on the findings of the study:

- Strategic routing can positively influence delivery time schedules, if the efficient freight forwarders align congruence between inbound and outbound port operations scheduling systems. Traffic congestion on national roads and highways affects the scheduled delivery times for many customers as the intermodal logistical system for the container delivery reflects congestion in the areas surrounding the Durban Port.

- The dynamics of the road freight transportation mode on the challenges of containerisation are determined by regulated road freight infrastructural design for full-truck loads and the magnitude of on-time delivery service levels to customers.

- Technological advancements provide a significant difference in mitigating systematic risk in the road freight networks and depict close synchronisation of inbound and outbound scheduling systems on the intermodal and inter-terminal integrated operations.

- The efficient use of the road freight transport mode can alleviate inbound and outbound traffic congestion by allocating a separate road lane for containerised full-truck loads, provided the customs clearance procedures are subjected to Transnet's central system (tracing, tracking and scanning) to expedite the prolonged delivery times to customers.

In addition, a further study on the effects of intermodal transportation on inbound and outbound networks within Durban containerisation could assist in the identification of the positive and negative aspects of choosing a specific mode and carrier. A comparative study between intermodal sea-road and sea-rail should also be undertaken to assess the leveraged strengths of both road and rail transport in South Africa. Capacity constraints could be addressed by the extension of port operations and storage areas, as well as the introduction of advanced technology in conjunction with training. It is recommended that further, similar studies be conducted on other South African ports such as Richards Bay and Cape Town.

\section{Conclusion}

This study informs role-players in logistical activities in and around the Durban Port of the issues pertaining to containers being transported using roads transport networks. Identifying these issues provides knowledge on the positive and negative aspects of choosing a specific mode and carrier, facilitates more streamlined movement of containers entering and exiting the Port of Durban and assists the industry to control external factors in order to limit costs and increase profitability. This could take South Africa to the 'next level' and ensure that its activities are on par with international markets and thus 
enhance the country's trading position. Dynamic and innovative technological systems and road infrastructural containership for port users and service providers have become increasingly interrelated and more integrated to consolidate the system of intermodal transportation. The integrated systems of containerisation on sea-road freight transport networks should reflect South Africa's increasing share of international trade.

\section{Acknowledgements Competing interests}

The authors declare that they have no financial or personal relationships that may have inappropriately influenced them in writing this article.

\section{Authors' contributions}

N.G. (Aramex South Africa) conducted the research project under the guidance of T.P.M. (University of KwaZulu-Natal), who served as study supervisor. T.P.M. then developed the article.

\section{References}

Barro-Torres, S.J., Fernandez-Carames, T.M., Gonzalez-Lopez, M. \& Escudero-Cascon, C.J., 2010, Maritime freight container management system using RFID, viewed 19 June 2012, from http://gtec.des.udc.es/web/images/pdfConferences/2010/ eurasiprfid barro 2010.pdf

Beins, B.C. \& McCarthy, M.A., 2012, Research methods and statistics, Pearson Education Inc., Upper Saddle River.

Borgatti, S.P. \& Li, H., 2009, 'On social network analysis in a supply chain', Journa of Supply Chain Management 45(20), 5-22. http://dx.doi.org/10.1111/j.1745493X.2009.03166.x

Bowersox, D.J., Closs, D.J., Cooper, M.B. \& Bowersox, J.C., 2013, Supply chain logistics management, 4th edn., McGraw-Hill, New York.

Bryman, A. \& Bell, E., 2007, Business research methods, 2nd edn., Oxford University Press, New York.

Caridi, M., Crippa, L., Perego, A., Sianesi, A. \& Tumino, A., 2010, 'Measuring visibility to improve supply chain performance: A quantitative approach Benchmarking: International Journal 17(4), 593-615. http://dx.doi. org/10.1108/14635771011060602

Caridi, M., Moretto, A., Perego, A. \& Tumino, A., 2014, 'The benefits of supply chain visibility: A value assessment model', International Journal of Production Economics 151, 1-19. http://dx.doi.org/10.1016/j.ijpe.2013.12.025

Cassidy, N., 2010, 'Container shortage hits shipping lines', BBC News, 28 June, viewed 22 May 2012, from http://www.bbc.co.uk/news/10432783

Cohen, J., Cohen, P., West, S.G. \& Aiken, L.S., 2003, Applied multiple regression/ correlation analysis for the behavioural sciences, 3rd edn., Lawrence Erlboum Associates, New York.

Cooper, D.R. \& Schindler, P.S., 2010. Business research methods, 8th edn., McGrawHill, New York.

Coronado Mondragon, A.E., Coronado Mondragon, E.S., Coronado Mondragon, C.E. \& Mung'au, F., 2012, 'Estimating performance of intelligent transport systems wireless services for multimodal logistics applications', Expert Systems with Applications 39(4), 3939-3949. http://dx.doi.org/10.1016/j.eswa.2011.08.161

Council of Scientific and Industrial Research, 2010, 7th State of logistics survey for South Africa: Value creation towards global competitiveness and sustainability viewed 05 May 2012, from http://local.sdklab.com/imperiallo/sites/default/files/ documents/7SoL.pdf

Coyle, J.J., Novack, A.R., Gibson, J.B. \& Bardi, J.E., 2011, Management of transportation 7 th edn., South-Western Cengage Learning, Boston

Cudahy, J.B., 2006, 'The containership revolution: Malcolm McLean's 1956 innovation goes global', TR News - The intermodal container era: History, security and trends 246, 5-9.

Department of Transport, 2011, Road freight strategy for South Africa, viewed 26 June 2013, from http://www.agbiz.co.za/uploads/documents/economic-intelligence/ agro-logistics/dot-national-freight-logistics-strategy.pdf

ExportHelp, 2010, Step 16: Handling the export logistics, viewed 12 May 2012, from http://www.exporthelp.co.za/modules/16_logistics/intro.html

Figueiredo, L.A., 2005, 'A industria de prestacao de servicos logisticos e o mdelo de negocio ASP: Perspectivas elendencias no mercaso brasileiro', PhD thesis, Universidade Federal de Santa Catarina.
Fu, D., Ionescu, C.M., Aghezzaf, E. \& Keyser, R.D., 2014, 'Decentralised and centralised model predictive control to reduce the bullwhip effect in supply chain management', Computers and Industrial Engineering 73, 21-31. http://dx.doi. management, Computers and
$\mathrm{org} / 10.1016 / \mathrm{j} . \mathrm{cie} .2014 .04 .003$

Goga, K., 2012, Globalisation and transnational organised crime in South Africa viewed 22 September 2012, from http://www.consultancyafrica.com/ index.php?option=com content\&view=article\&id=1029:globalisation-andtransnational-organised-crime-in-south-africa- \&catid=60: conflict-terrorismdiscussion-papers\&ltemid $=265$

Hanaoka, S. \& Regmi, M.B., 2011, 'Promoting intermodal freight transport through the development of dry ports in Asia: An environmental perspective', IATSS Research 53, 16-23. http://dx.doi.org/10.1016/j.iatssr.2011.06.001

Havenga, J., Simpson, Z. \& De Bod, A., 2012, 'South Africa's domestic intermodal imperative', Research in Transportation Business and Management 5, 38-47. http://dx.doi.org/10.1016/j.rtbm.2012.11.006

Hayuth, Y., 1987, Intermodality: Concept and practice, Lloyd's of London Press Ltd, London.

International Organisation of Standards, 2009, ISO-conforming RFID tags for freight containers ready for the worst, viewed 19 May 2012, from http://www.iso.org/ iso/home/news_index/news_archive/news.htm?refid=Ref1205

Kim, D., 2014, 'Understanding supplier structural embeddedness: A social network perspective', Journal of Operations Management 32(5), 219-231. http://dx.doi. org/10.1016/j.jom.2014.03.005

Kunene, O. \& Allopi, D., 2011, Assessment of road infrastructure within the port of Durban, viewed 19 June 2012, from http://www.imesa.org.za/images/ conf2010papers/18.pdf

KZN Department of Transport, 2011, Port of Durban, viewed 17 May 2012, from http://freightdb.kzntransport.gov.za/index.php?option=com content\&view=arti http://freightdb.kzntransp
cle\&id=19\&Itemid=158

Li, C., 2013, 'Controlling the bullwhip effect in a supply chain system with constrained information flows', Applied Mathematical Modelling 37, 1897-1909. http:// dx.doi.org/10.1016/j.apm.2012.04.020

McBurney, D.H. \& White, T.L., 2004, Research methods, 6th edn., Thomson Wadsworth, Belmont.

McBurney, D.H. \& White, T.L., 2007, Research methods, 7th edn., Thomson Wadsworth, Belmont.

Miller, T., 2001, Container matters, viewed 19 May 2012, from http://www.ukpandi. $\mathrm{com} /$ fileadmin/uploads/uk-pi/LP\%20Documents/LP_News/Container\%20 Matters.pdf

Mokhtar, K., 2013, 'Technical efficiency of container terminal operations: A DEA approach', Journal of Operations and Supply Chain Management 6(2), 1-19. http://dx.doi.org/10.12660/joscmv6n2p1-19

Musa, A., Gunasekaran, A. \& Yusuf, Y., 2014, 'Supply chain product visibility: Methods, systems and impacts', Expert Systems with Applications 41(1), 176-194. http:// dx.doi.org/10.1016/j.eswa.2013.07.020

Newbert, S.L., 2007, 'Empirical research on the resource-based view of the firm: An assessment and suggestions for future research', Strategic Management Journa 30(8), 909-920.

Ngcobo, L., 2009, Transnet is the world's first port operator to manage Navis ${ }^{T M}$ SPARCS N4 from one central location across multiple sites, viewed 13 August 2014, from http://ports.co.za/sapo/article_2009_03_19_3307.html

Northport, 2009, History of containers, viewed 22 May 2012, from http://www. northport.com.my/docs/thehistoryofcontainer.pdf

Oliveira, T., Thomas, M. \& Espadanal, M., 2014, 'Assessing the determinants of cloud computing adoption: An analysis of the manufacturing and services sectors', Information and Management 51, 497-510. http://dx.doi.org/10.1016/j. im.2014.03.006

Organisation for Economic Development and Cooperation, 2001, Intermodal freight transport: Institutional aspects, OEDC, Paris.

Pagell, M., Wu, Z. \& Murthy, N.N., 2007, 'The supply chain implications of recycling', Business Horizons 59(2), 133-143. http://dx.doi.org/10.1016/j. bushor.2006.08.007

Pienaar, W.J. \& Vogt, J.J., 2009, Business logistics management - A supply chain perspective, 3rd edn., Oxford University Press, Cape Town.

Port Technology, 2014, 'TPT implement Navis terminal operating systems in South Africa', Port Technology, 02 June, viewed 13 August 2014, from http://www. porttechnology.org/news/tpt_implement_navis_terminal_operating_system_in_ south_africa

Raymond, C.G., 2006, 'World trade security is attainable and imperative: Cooperative effort, US leadership are necessary', TR News - The intermodal container era: History, security and trends 246, 18-23.

Roberti, M., 2005, 'RFID container seals deliver security, value', RFID Journal, 31 October, viewed 20 May 2012, from http://www.rfidjournal.com/article/ view/1965

Rogers, E.M., 2003, Diffusion of innovation, 5th edn., Free Press, New York.

Rugman, A.M. \& Verbeke, A., 1998, 'Corporate strategies and environmental regulations: An organising framework', Strategic Management Journal 19(4), 363-375. http:// dx.doi.org/10.1002/(SICI)1097-0266(199804)19:4<363::AID-SMJ974>3.0.CO;2-H

Scheinberg, T., 2009, 'Transnet is the world's first port operator to manage Navis ${ }^{\mathrm{TM}}$ SPARCS N4 from one central location across multiple sites', Ports \& Ships, 1-2.

Sekaran, U. \& Bougie, R., 2010, Research methods for business, 5th edn., John Wiley and sons Ltd, Chichester. 
Shuttleworth, M., 2010, Quantitative research designs, viewed 23 August 2012, from https://explorable.com/quantitative-research-design

Sodero, A.C., Rabinovich, E. \& Sinha, R.K., 2013, 'Drivers and outcomes of openstandard interorganisational information systems assimilation in high-technology supply chains', Journal of Operations Management 31, 330-344. http://dx.doi. org/10.1016/j.jom.2013.07.008

SPSS Statistics version 19, 2010, computer software, IBM, Chicago.

Tate, W.L., Ellram, L.M. \& Golgeci, I., 2013, 'Diffusion of environmental business practices: A network approach', Journal of Purchasing \& Supply Management 19, 264-275. http://dx.doi.org/10.1016/j.pursup.2013.08.001

Teece, D.J., 2007, 'Explicating dynamic capabilities: The nature and micro foundations of (sustainable) enterprise performance', Strategic Management Journal 28(13), 1319-1350. http://dx.doi.org/10.1002/smj.640

Teece, D., Pisano, G. \& Shuen, A., 1997, 'Dynamic capabilities and strategic management', Strategic Management Journal 18(7), 509-533. http://dx.doi. org/10.1002/(SICI)1097-0266(199708)18:7<509::AID-SMJ882>3.0.CO;2-Z

Teo, T.S.H., Lin, S. \& Lai, K.H., 2009, 'Adopters and non-adopters of e-procurement in Singapore: An empirical study', Omega 37(5), 972-987. http://dx.doi. org/10.1016/j.omega.2008.11.001
Teravaninthorn, S. \& Raballand, G., 2009, Transport prices and costs in Africa, World Bank, Washington, DC.

Tornatzky, L.G. \& Fleischer, M., 1990, The processes of technological innovation, Lexington Books, Lanham.

Transnet, 2011a, Durban container terminal, viewed 19 June 2012, from http://www. transnet-tpt.net/Ports/Pages/Durban_Container.aspx

Transnet, 2011b, Navis (SPARCS N4) - A simplified user guide, viewed 05 May 2013, from http://www.transnet.net/Divisions/TPT\%20Documents/Navis\%20 Users\%20Guide.pdf

Trochim, W., 2006, Nonprobability sampling, viewed 23 August 2012, from http:// www.socialresearchmethods.net/kb/sampnon.php

Walker, J., 2010, Research methods and statistics, Palgrave Macmillan, London.

Walliman, N., 2001, Your research project: A step to step guide for first time researcher, Sage Publications, New York.

Zhu, K., Dong, S., Xu, S.X. \& Kraemer, K.L., 2006, 'Innovation diffusion in global contexts: Determinants of post-adoption digital transformation of European companies', European Journal of Information Systems 15, 601-616. http://dx.doi. org/10.1057/palgrave.ejis.3000650 